\title{
International Human Rights Law and the Protection of the Elderly in Europe
}

\begin{abstract}
SARA TONOLO
Abstract The protection of the elderly is a fundamental topic within the international human rights law, strictly connected to the perceived centrality of a person with disabilities as subject of rights. Some problems may arise as much from the absence of a uniform definition of elderly people and of person with disabilities, as from the different national rules on this matter. In fact the rights of elderly people have not yet received the international legal attention they deserve. Many treaties refer to rights that are of particular interest to the elderly, but there is no comprehensive international instrument that adequately addresses the specific protections required for the elderly. Actually, standards that protect older people's rights are scattered throughout various international and regional conventions. There is no doubt that the elderly are protected by human rights treaties, as is any member of society, however, in order to realistically guarantee equal enjoyment of those rights to older persons, states must do more than refrain from violating human rights of every member of society.

Keywords: • Human Rights • Elderly Persons - CRPD • Ageing Society • International Law •
\end{abstract}

CORRESPONDENCE ADDRESS: Sara Tonolo, Professor of International Law, University of Trieste, Department of Political and Social Sciences, P.le Europa 1, Trieste, Italy, e-mail: sara.tonolo@dispes.units.it. 

The Society of the 21st Century is generally defined as an Ageing Society. Recent Studies highlight that future demography will comprise an extraordinary super-aged society and that this demographic trend is, more or less, shared by many states both in developed and developing countries. By 2025, more than 1.2 billion people will be aged sixty or above, and more than seventy percent of them will be residing in what are currently considered developing countries (Economic, Social and Cultural Rights of Older Persons: General Comment 6, U.N. ESCOR, Econ., Soc., \& Cultural Rts. Comm., 13th Sess., para.1, UN Doc. E/C.12/1995/16/Rev.1 (1995) [hereinafter General Comment 6]). Actually, Asia and Europe are ageing the most rapidly, as outlined by the WHO report (World Report in Ageing and Health 2015). Such an extraordinary trend will significantly alter society in the sense that a great percentage of the total population will not have adequate mental capacity that is usually required to carry out day-to-day activities.

Older persons historically have been neglected by human rights law, but recently significant demographic changes have renewed the general interest in older persons' human rights. International law addresses this particular challenge to some extent. The purpose of the law, when it comes to the elderly, is to help protect them from abuses, particularly those of an economic, physical or mental nature. More generally, the protection of persons with disabilities is a fundamental issue in the area of international human rights law, as the necessity of considering the needs and concerns of persons with disability is a generally accepted principle (Tonolo, 2013: 273).

\section{Human Rights Law and Rights of older persons.}

Human rights law has not sufficiently taken into account the special and unique needs of the elderly. There are many international instruments that recognize specific rights of all persons and are clearly applicable to elderly people as citizens of signatory states, as well as regional human rights conventions.

None of the equality clauses of the 1948 Universal Declaration of Human Rights UDHR (GA Res. 217 A (III), 10.12.1948), of the 1966 International Covenant of Civil and Political Rights- ICCPR (999 UNTS 171), and of the 1966 International Covenant on Economic, Social and Cultural Rights - ICESCR (993 UNTS 3), mention older persons as well as persons with disability as protected categories. For international human rights law, the principle of non - discrimination and equality is a value in itself that can be derived directly from human dignity (McCrudden, 2004: 581). 
Of particular significance to old age is Article 25(1) of the UDHR that states that everyone has the right to security and a 'standard of living adequate for the health and well-being of himself and his family'.

The two Conventions, the ICESCR and the ICCPR, offer generic protection of cultural, economic, social, civil and political rights. For older persons, important specific rights in the ICESCR are the work-related rights (Articles 6-7) and the rights to social security (Article 9), to an adequate standard of living (Article 11), to education (Article 13) and to the highest attainable standard of physical and mental health (Article 12).

The ICESCR itself does not contain any direct references to older persons. In 1995, the Committee on Economic, Social and Cultural Rights (CESCR) released General Comment No. 6 on 'the economic, social and cultural rights of older persons'. The comment provides a legal interpretation of how the ICESCR ought to apply to older persons. It explains that the omission of 'age' specifically as an illegal ground of discrimination was not intentional, but occurred because when the ICESCR and ICCPR were adopted, 'the problem of demographic ageing was not as evident or as pressing as it is now'.

In the ICCPR, 'participation rights' of special concern for older persons are the commitment of states to ensure freedom of expression, assembly and association (Articles 18-19,21). Article 25 recognises the right of all to participate in the affairs of their own country. Article 26 states 'All persons are equal before the law and are entitled without any discrimination to the equal protection of the law'. The article includes race, colour, sex, language, religion, origin 'or other status' as prohibited grounds of discrimination. 'Age' is not mentioned explicitly, yet might be said to be included implicitly in the 'and other status' language.

Several UN treaties have been created in order to deal specifically with the rights of disadvantaged groups. Although none of these focus specifically on older persons, a few mention 'age'. The Convention on the Elimination of All Forms of Discrimination Against Women (CEDAW), for example, mentions 'age' in Article 11 , in the context of the equal rights of women and men to social security and paid leave. Similarly, the Convention on the Protection of the Rights of Migrant Workers and the Members of their Families (ICMW) includes 'age' in the list of prohibited grounds of discrimination in Article 7. However, it is generally recognized that the elderly population remains a vulnerable group with no legal instrument tailored to its particular needs (Pinzón \& Martin, 2003: 918; von Bernstorff, 2007: 1041). 
The most useful protection for older persons may be found in the Convention on the Rights of Persons with Disabilities-CRPD, adopted in 2007 and now ratified by about 160 UN members (Convention 30. 3.2007 n. 61/106, GA Res. 61/611, 13.12.2006, A/61/611; 15 IHRR 255. ${ }^{1}$

The CRPD represents the most organic system of rules and guarantees for the protection of vulnerable people, inspiring also other provisions, such as for example those referred to in the Nice Charter (Article 25-recalled by the Lisbon Treaty, OJEU, C 303/17 - 14.12.2007), according to which: "The Union recognises and respects the rights of the elderly to lead a life of dignity and independence and to participate in social and cultural life."

The General Assembly Mandate, under which the Convention on Rights of persons with disabilities was developed, stipulated that the negotiating Committee was to put into practice the existing human rights in the particular circumstances of persons with disability. In spite of this, the Convention is a core constituent of international human rights law, rather than a subsidiary of existing law. Articles 3 to 9 contain overarching principles to be applied in the implementation of the convention. Article 4 sets out the general obligation to incorporate the terms of the convention into national laws, policies and programs, and to repeal national laws that are inconsistent with the convention.

It is remarkable the procedural aspect of the Convention, concerning the procedures offered to protect the rights established, reffered to the Committee on the Rights of Persons with Disabilities, competent to carry out consultative activities - to control the respect of the Convention by the States, but also to examine appeals proposed by individuals and associations. Under the Optional Protocol (art. 1), the treaty body is also empowered to receive complaints about violations of rights from individuals and groups of individuals where they have exhausted domestic remedies. The Optional Protocol also establishes an inquiry procedure in relation to gross violations of fundamental rights (International Legal Materials 2007, 441).

The purpose (Article 1) of the CRPD states that "persons with disabilities include those who have long-term physical, mental, intellectual or sensory impairments which in interaction with various barriers may hinder their full and effective participation in society on an equal basis with others." Article 12, "equal recognition before the law," mentions that "parties shall take appropriate measures to provide access by persons with disabilities to the support they may require in exercising their legal capacity." The latter article implies a possible paradigm shift from

\footnotetext{
${ }^{1}$ See Disabilities - Handbook on the Convention on the Rights of Persons with Disabilities and its Optional Protocol (Geneva: OHCHR, 2007: available at: http://www.ohchr.org/english/aboutt/publications/docs/ExclusionEqualityDisabilities.pdf).
} 
substitute decision-making to supported decision-making in order to understand the principals' will and preferences, and to implement their wishes.

Even if older persons may be considered as persons to be protected according to the CRPD rules, and even if they are generally protected under international human rights law, the general protection highlights a wide range of normative gaps, where aspects of the lives of older people are not addressed adequately by existing human rights law, for example: international standards on rights within community-based and long-term care settings for both the caregiver and the person receiving care; legal planning for older age; and, the abolition of mandatory retirement ages.

\subsection{Definitions of Older Persons and Problems of Characterization}

The definition of «persons with disabilities» was one of the most controversial topics dealt with by the CRPD. Among State delegations, the principal reason for this was concern about the impact of such definitions on different national systems. Article 1 describes persons with disabilities as "...those who have long - term physical, mental, intellectual or sensory impairments...". This notion seems openended and propositional, also because it is stated in the rule devoted to the application of the Convention (art. 1) and not in the Article 2, which is specifically aimed at the definition of five key terms used throughout the Convention. Accordingly, it seems possible to extend the application of the Convention to persons with short-term impairments, arising for example from traumatic injuries and disease, and to persons with episodic conditions (e.g. mood disorders, asthma).

On this matter, it should also be noted that Article 1, par.1, asserts that the purpose of the Convention is "to promote, protect and ensure the full and equal enjoyment of all human rights and fundamental freedoms by all persons with disabilities".

The boundaries of the category of persons to benefit from the Convention are also uncertain and variable because they are to be determined domestically.

However the perceived centrality of persons with disabilities as «subjects of rights, able to claim those rights as active members of society» (statement by Arbour, UN High Commissioner for Human Rights on the Ad Hoc Committee's adoption of the International Convention on the Rights of Persons with Disabilities, 5 December 2006 , available

at http://www.ohchr.org/English/issues/disability/docs/statementhcdec06.doc) must be stressed as a fundamental element to include elderly persons within the field of action of the CRPD. Although certainly not all older persons have disabilities, and while the Convention does not single out elderly people for special protection, nevertheless many of its articles can be utilised by older persons seeking human rights protection. 
Moreover, in interpreting the definition of persons to protect, we may also be able to find relevant constructive clues in other sources, such as for example in the 2000 Hague Convention on the International Protection of Adults, internationally in force since 1 January 2009 (The Convention was drawn up under the auspices of the Hague Conference on Private International Law, to replace the 1905 Hague Convention. The text is published in International Legal Materials, vol. 39, 2000; 7; see Siehr, 2000: 715; Clive, 2000: 1; Fagan, 2002: 329). The purpose of this Convention is in fact to organize "the protection in international situations of adults who, by reason of an impairment or insufficiency of their personal faculties, are not in a position to protect their interests" (Art. 1, par. 1: Kayess \& French, 2008: 1; Lagarde, 2000: 159).

\subsection{Rules of the CRPD Concerning Older Persons}

The principles of the CRPD are particularly relevant to older persons: respect for dignity; non-discrimination; full participation and inclusion in society; equality of opportunity; and accessibility (Article 3). Article 8 obliges states to combat stereotypes and prejudices relating to persons with disabilities, including those based on sex and age. Article 12 affirms the right of disabled persons to equal recognition before the law. It requires that states shall recognize that persons with disabilities are to enjoy legal capacity on an equal basis with others in all aspects of life, and that this includes taking appropriate measures to provide access by persons with disabilities to the suppot they may require in exercising their legal capacity Art. 12, para. 1-3).

'Older persons' are referred to in Article 25(b) of the CRPD, which concerns itselfwith the right to health services, and in Article 28(2)(b), which deals with the right to access to social protection and poverty reduction programs. Article 13(1), which governs access to justice, refers to 'age-appropriate accommodations'. Article 16(2) mentions the right to 'age-sensitive assistance' by states to ensure freedom from exploitation, violence and abuse. Other articles in the CRPD that could potentially benefit older persons are Article 9 on accessibility, Article 19 on independent living, Article 20 on personal mobility and Article 26 on habitation.

Even if interpretative clues to protect older persons may be deemed right by the CRPD rules, there are still some normative gaps to solve: international standards on rights within community-based and long-term care settings for both the caregiver and the person receiving care; legal planning for older age; the abolition of mandatory retirement ages; and, legal capacity and equality before the law for older women and men. 
The implementation of the aforementioned rules concerning human rights of older persons is uncertain and often conditioned by soft law rules. In 1982, the World Assembly on Ageing adopted the Vienna International Plan of Action on Ageing (VIPAA). This was the first UN Human rights instrument on ageing. Its recommendations included avoiding the segregation of the elderly, making available home-based care for elderly persons, rejecting stereotypical concepts in government policies and recognising the value of old age. Twenty years later, the Madrid International Plan of Action on Ageing (MIPAA) was adopted as an updated and greatly expanded version at the Second World Assembly on Ageing. The Political Declaration reaffirmed the commitment to the elimination of age discrimination, to enhance the recognition of dignity in older persons, their inclusion in society, and the promotion of their human rights in general.

In 1991, the UN General Assembly adopted resolution 46/91, the United Nations Principles for Older Persons. It lists principles in five areas which governments are encouraged to include in national policies: independence, participation, care, selffulfilment and dignity. a Proclamation on Ageing was adopted.

A Proclamation on Ageing was adopted in 1992, a decade after the first World Assembly on Ageing.

The UN Secretary-General's report (2011) on the follow-up to the Second World Assembly on Ageing concludes that some good measures have been introduced since 2002 with regard to older persons' rights. However, these policies are inconsistent among nation-states and do not indicate the presence of a comprehensive legal, policy and institutional framework for the protection of the human rights of older persons. Particularly lacking are mechanisms of participation and accountability. In varying degrees, contributions (Lawson, 2007: 563; Seatzu, 2008: 542) underline deficits in implementation of policies, when available, while others note measures may be effective but insufficient when confronted with large and growing demands. In situations where more structural measures are required, some governments have chosen a welfare approach which may not ensure sustainability or long-term impact on the enjoyment of human rights without discrimination (UN Secretary-General, 2011).

In sum, the international soft law protection of the human rights of older persons is wide-ranging and while providing useful guidelines for state action in setting standards and influencing domestic policies, however, none of the documents contains legally binding obligations.

As result, implementation can be weak, and states often fail to incorporate these international standards into their domestic policies (see http://social.un.org/ageing- 
S. Tonolo: International Human Rights Law and the Protection of the Elderly in Europe

working-

group/documents/Table\%20HR\%20\&\%20MIPAA\%20\%20April\%202011.pdf).

\section{$5 \quad$ Regional Systems}

Some standards that protect older people's rights are scattered throughout regional conventions. Generally speaking, in the European and Inter-American systems, the provisions on elderly rights are embodied in economic, social, and cultural rights treaties, while the African System protects those rights alongside civil and political rights in a unique instrument. The Council of Europe (COE) Committee of Ministers, in 2014, adopted a non-binding Recommendation on the promotion of the human rights of older persons. While the COE Commissioner for Human Rights does not have a particular focus on older person's rights, the European Court of Human Rights has addressed this topic in a variety of cases (see infra $\S 6$ ). The European Union has adopted the aforementioned Charter of Fundamental Rights. This Charter, which applies exclusively to the states that are members of the European Union, includes an ambitious and innovative list of human rights covering the range of civil, political, economic, and social rights. In relation to the protection of the elderly, Article 25 states: "The [European] Union recognises and respects the rights of the elderly to lead a life of dignity and independence and to participate in social and cultural life." The Explanatory Report indicates that this right must be interpreted in the light of Article 23 of the Revised European Social Charter and two provisions of the Community Charter of the Fundamental Social Rights of Workers see $\S 6$ (CHARTE 4473/00 CONVENT 50 (explaining that Article 25 draws on the revised European Social Charter Article 23), available at http://www.europarl.eu.int/charter (last visited Feb. 24, 2003).

In the African human rights system, the Protocol to the African Charter on Human and Peoples' Rights on the Rights of Older Persons in Africa was adopted in January 2016, but it has not yet come into force. Also within the African regional system, under the African Commission on Human and Peoples' Rights, the Working Group on Rights of Older Persons and People with Disabilities works to protect the rights of elderly people.

The Inter-American human rights system-adopted the first binding convention on the rights of older persons, the Inter-American Convention on Protecting the Human Rights of Older Persons on December 12, 2016. [(adopted 15 June 2015, into force since January 2017), A-70.] The purpose of the Convention is to recognize, promote, and protect the rights of older persons, generally defined as people aged 60 or older, except when legislation determines an age that is lesser or higher so long as it is not over 65 years (Art. 2), and establishes that as people age they should continue to enjoy and exercise all human rights and fundamental freedoms on an equal basis with other segments of society. To this end, the Convention draws on existing principles established in nonbinding, or soft law, instruments to enumerate 
26 protected rights and also establishes a follow-up mechanism to monitor the implementation of the commitments under the Convention, which includes a reporting procedure and the ability of individuals to submit petitions alleging violations of the Convention to the Inter-American Commission on Human Rights.

The Convention lists general principles related to the rights and fundamental freedoms of older persons, with a focus on equality and non-discrimination stated at Art. 3. Further, the Convention emphasizes the dignity, independence, and autonomy of older persons as well as their physical, economic, and social security. It also calls for the respect and appreciation of cultural diversity, effective judicial protection, proper treatment and preferential care. The Convention lists several general duties of States parties, that have a duty to adopt measures to prevent, punish, and eradicate practices contrary to the Convention and to adopt affirmative measures and make the necessary changes in domestic legislation so that older persons can exercise the rights established in the Convention.

More specifically, Articles 5 through 31 of the Convention list the various protected rights of older persons: the right of older persons to safety and a life free of violence of any kind; right to receive long-term care; right to work; right to health, including physical, mental, and social health; right to education; right to housing, emphasizing policies that progressively adapt housing solutions so that they are architecturally suitable for older persons, policies that ensure expedited procedures for complaints regarding evictions, and measures to protect older persons from illegal forced evictions; and, the right to accessibility and personal mobility. The rights of older persons receiving long-term care are detailed in Article 12 of the Convention. Article 12 encompasses the right to a comprehensive system of care that promotes the health of older persons, provides social services that cover food and nutrition security, promotes the ability of older persons to live in their own home and maintain their autonomy, and provides services for families and caregivers. To ensure this right is fulfilled, the Convention calls on States parties to establish mechanisms that ensure long-term care services are subject to the free and express will of older persons and that such services have specialized personnel. Additionally, it requires States parties to establish a regulatory framework that ensures access to information for older persons; prevents arbitrary or illegal intrusions in any sphere in which older persons are involved; protects older persons' personal security, freedom of movement, and their integrity in all aspects of their lives - particularly in acts of personal hygiene.

Article 18 of the Convention elaborates on older persons' right to work. The right to work encompasses anti-discriminatory policies and procedures that promote more inclusive labor markets guaranteeing the same rights, benefits, and protections to all workers for similar tasks and responsibilities, regardless of age. In particular, Article 18 includes measures that would facilitate the gradual transition into 
retirement and expand on labor policies that account for the needs and characteristics of older persons.

The Convention foresees two processes for monitoring and assessing States parties' compliance with its provisions. Article 35 establishes a Committee of Experts composed of individual experts, appointed by States parties, who will be tasked with monitoring and reviewing States' implementation of the Convention through a periodic reporting process. States parties would be required to submit an initial report on their compliance with the Convention within one year of the Committee's first meeting and submit follow-up reports every four years after that. The Committee of Experts will be based at the OAS Headquarters in Washington, D.C. Additionally, Article 36 authorizes individuals, groups of individuals, and nongovernmental organizations to submit complaints of allegations of the Convention by a State party to the Inter-American Commission on Human Rights. States parties may also submit a specific declaration recognizing the competence of the InterAmerican Commission to hear inter-State complaints under the Convention. The Convention also expressly authorizes States parties to accept the Inter-American Court of Human Rights' jurisdiction to hear complaints against it involving the Convention.

\section{The protection of older persons in the European Human Rights System}

The European Human Rights System refers in particular to the treaties adopted within the Council of Europe, which mainly consist of the European Convention on Human Rights (European Convention on Human Rights European Convention for the Protection of Human Rights and Fundamental Freedoms, opened for signature Nov. 4, 1950, 213 U.N.T.S. 222, E.T.S. No. 005.) and the Revised European Social Charter. The 1988 Additional Protocol to the European Social Charter articulates protection for the rights of elderly persons in Article 4 (Additional Protocol to the European Social Charter, opened for signature May 5, 1988, art. 4, E.T.S. No. 128 (entered into force Apr. 9, 1992) (addressing the rights of the elderly to social protection), available at

http://conventions.coe.int/Treaty/EN/CadreListeTraites.htm).

Despite the fact that rights of older persons do not appear as such in the ECHR, elderly people do find their way to the ECtHR. This is possible as the right to a fair trial and the right to non-discrimination are fundamental guarantees that can be used creatively to protect elder persons from certain practices such as forced retirement and slow judicial proceedings regarding health or social benefits. Similarly, provisions prohibiting cruel and degrading treatment have special meaning and provide specific protections for the elderly in circumstances such as serving labor prison sentences, serving jail time for a crime, and receiving inhumane treatment in 
health facilities. Moreover, through the right to property, the elderly may protect their rights to pensions and social security benefits.

In several cases, the ECtHR applied certain civil and political rights recognized in the European Convention on Human Rights to the elderly. In the Deumeland case (Deumeland v. Germany, 100 Eur. Ct. H.R. (ser. B) (1986), available at http://www.echr.coe.int), Johanna Deumeland applied for a widow's supplementary pension, arguing that an industrial accident had caused her husband's death. After her death during the proceedings before the ECtHR, her son continued the proceedings and brought the petition to the European Human Rights System upon exhausting domestic remedies. The applicant claimed that the German courts had not given the case a fair hearing within a reasonable time, which violated Article 6 paragraph 1 of the European Convention on Human Rights. The Court assessed the reasonableness of the length of the Deumeland proceedings with regard to criteria established by the Court's case law, namely: the degree of complexity of the case, the behavior of the applicant, and the conduct of the competent courts.

In several cases, the ECtHR affirmed that there is no prohibition in the Convention against the detention in prison of persons who attain an advance age. Nevertheless, a failure to provide the necessary medical care to prisoners may constitute inhuman treatment and there is an obligation on States to adopt measures to safeguard the well-being of persons deprived of their liberty. Whether the severity of the illtreatment or neglect reaches the threshold prohibited by Article 3 (prohibition of inhuman or degrading punishment or treatment) of the Convention will depend on the particular circumstances of the case, including the age and state of health of the person concerned as well as the duration and nature of the treatment and its physical or mental effects (see Sawonjuk v. UK, 29 May 2001; Priebke v. Italy, 5 April 2001; Enea v. Italy, 17 September 2009). In the case Contrada v. Italy (11 February 2014), the Court held that there had been a violation of Article 3 (prohibition of inhuman or degrading treatment) of the Convention. It observed in particular that it was beyond doubt that the applicant had suffered from a number of serious and complex medical disorders, and that all the medical reports and certificates that had been submitted to the competent authorities during the proceedings had consistently and unequivocally found that his state of health was incompatible with the prison regime to which he was subjected. The Court further noted that the applicant's request to be placed under house arrest had not been granted until 2008, that is to say, until nine months after his first request. In the light of the medical certificates that had been available to the authorities, the time that had elapsed before he was placed under house arrest and the reasons given for the decisions refusing his requests, the Court found that the applicant's continued detention had been incompatible with the prohibition of inhuman or degrading treatment under Article 3 of the Convention.

About the right to a fair trial, the ECtHR held in several cases that there had been a violation of Article $6 \S 1$ (right to fair trial) of the Convention in respect to the length 
of proceedings, having regard more particularly to the fact that in view of the applicants' old age the national courts should have displayed particular diligence in handling these cases (see Jablonskà v. Poland, 9 March 2004; Schlumpf v. Switzerland, 8 January 2009; Georgel and Georgeta Stoicescu v. Romania, 26 July 2011).

\section{$5 \quad$ Conclusive Remarks}

Even if the human rights law is recently focusing on older persons, there are many international treaties and conventions offering generic human rights protection that implicitly include the protection of this weak category. In addition to binding law, there are soft law provisions - the MIPAA and General Comment No.6 on the ICESCR being the most prominent - that guide the application of law and add to the overall protection of older people. However, many NGOs, as well as some UN member states, argue that these instruments fail to provide explicit support and are easily subject to ageist interpretation (see, for example, HelpAge International, 2009). These organisations argue for the need for a new international human rights instrument explicitly for the protection on older persons - a Convention on the Rights of Older Persons.

With Resolution 65/182 in December 2010, the UN General Assembly established an Open-Ended Working Group on Ageing for the purpose of strengthening the protection of the human rights for older persons. The task of the group was to evaluate the current international human rights framework for older persons, to identify gaps and how best to address them, and to consider the possibility of additional instruments and measures (UNOEWG 2011). The Human Rights Council appointed the first Independent Expert on the enjoyment of all human rights by older persons, Rosa Kornfeld-Matte, in May 2014. The goal of the mandate is to address the specific challenges and vulnerabilities of older persons and to strengthen the protection of their human rights at a time when about 700 million people around the world are over the age of 60. In her latest report to the Human Rights Council, Kornfeld-Matte emphasized the issues of accessibility, education, the right to work, and violence and abuse, among others, that particularly affect older persons.

Despite several doubts on the proceeding concerning the adoption of a new convention, it is possible to agree about the fact that the persistence of ageism and age discrimination bears witness to the failure of governments around the world to incorporate older persons' rights in their policies, highlighting the need for a new instrument. Actually, standards that protect older people's rights are scattered throughout various international and regional conventions.

There is no doubt that the elderly are protected by human rights treaties, as is any member of society. However, in order to realistically guarantee equal enjoyment of those rights to older persons, states must do more than refrain from violating human 
rights. The principles of non-discrimination and equality before the law require that states adopt special measures to protect disadvantaged and vulnerable groups, considering the international standards of protection (Revillard, 2005: 725). Moreover, the "vulnerable group" approach is central to enhancing the protection of those rights because it is applicable in the context of both civil and political, as well as economic, social, and cultural rights (Bucher, 2000: 37).

Bringing the relevant provisions together in one text, as was successfully done for the rights of women, children and disabled people, would bring clarity to both the nature of older people's rights and the responsibilities necessary to protect them.

\section{References}

von Bernstorff, J. (2007) Menschenrechte und Betroffenrepräsentation: Entstehung und Inhalt eines UN-Antidiskriminierungsübereinkommens über die Rechte von behinderten Menschen, Zeitschrift für ausländisches öffentliches Recht und Völkerrecht, 67, pp. 1041-1063, available at: http://www.zaoerv.de/67_2007/67_2007_4_a_1041_1064.pdf (September 12, 2018).

Bucher, A. (2000) La Convention de La Haye sur la protection internationale des adultes, Schweizerische Zeitschrift für internationales und europäisches Recht : SZIER = Revue suisse de droit international et de droit européen = Rivista svizzera di diritto internazionale e di diritto europeo $:$ RSDIE $=$ Swiss review of international and european law : SRIEL, 10(1), pp. 37-74.

Clive, E. (2000) The New Hague Convention on the protection of adults, Yearbook of Private International Law, 2, pp. 1-23.

Fagan, A. R. (2002) An analysis of the Convention on the international protection of adults, in Elder Law Journal, 10(2), pp. 329-359.

Kayess, R. \& French, P. (2008) Out of darkness into Light? Introducing the Convention on the Rights of Persons with Disabilities, Human Rights Law Review, 8(1), pp. 1-34, doi: $10.1093 / \mathrm{hrlr} / \mathrm{ngm} 044$.

Lagarde, P. (2000) La Convention de la Haye du 13 janvier 2000 sur la protection internationale des adultes, Revue critique de droit international, 89, pp. 159-179.

Lawson, A. (2007) The United Nations Convention on the Rights of Persons with disabilities: New Era or False Dawn?, Syracuse Journal of International Law and Commerce, 34(2), pp. 563-619.

McCrudden, J. C. (2004) Equality and Non - Discrimination, in: Feldman, D. (ed.) English Public Law (Oxford: Oxford University Press), pp. 581-607.

Pinzón, D. R. \& Martin, C. (2003) The International Human Rights Status of Elderly Persons, American University International Law Review, 18(4), pp. 915-1008.

Revillard, M. (2005) La Convention de La Haye sur la protection internationale des adultes et la pratique du mandat d'inaptitude, in: Le droit international privé: esprit et méthodes. Mélanges en l'honneur de Paul Lagarde (Paris: Dalloz)-p. 725;

Seatzu, F. (2008) La Convenzione delle Nazioni Unite sui diritti delle persone disabili: i principi fondamentali, Diritti umani e diritto internazionale, 3, pp. 535-559.

Siehr, K. (2000) Das Haager Übereinkommen über den internationalen Schutz Erwachsener, Rabels Zeitschrift für ausländisches und internationales Privatrecht, pp. 715-751. 
Tonolo, S. (2013) The protection of persons with disabilities in private international law, Cuadernos de derecho transnacional, 5(1), pp. 273-280. 

